\title{
E-Learning as a Means to Improve the Quality of Higher Education
}

\author{
Marina Kuimova ${ }^{1, \mathrm{a}}$, Anastasiya Kiyanitsyna ${ }^{1}$, and Alexey Truntyagin ${ }^{2}$ \\ ${ }^{1}$ National Research Tomsk Polytechnic University, 634050, Lenin Avenue, 30, Tomsk, Russia \\ ${ }^{2}$ National Research Tomsk State University, 634050, Lenin Avenue, 36, Tomsk, Russia
}

\begin{abstract}
The use of e-learning has become an important part of higher education. It expands the pedagogical resources, assists students in their learning, develops learners' skills, motivation and knowledge, prepares them for being productive in their workplaces of today's society. The paper provides the literature review regarding the use of e-learning, its advantages and disadvantages. The authors examine students' perception of e-learning courses based on the Moodle platform at National Research Tomsk Polytechnic University. The findings from a survey of 67 students reveal that the respondents highlighted the following advantages of e-learning courses: convenience, combination of theoretical and practical material, on-line testing and apprehensibility of the assessment criteria.
\end{abstract}

\section{Introduction}

The last few decades can be characterized as the formative period of a new information culture and of a sharp increase in the role of information technology and technological content in all fields including education. Nowadays ICT (information and communications technology: computer technologies of training, interactive multimedia, web-based training, online training, etc.) has turned into an effective educational technology and is actively introduced into teaching and learning of all countries. Therefore, the distinctions between distance learning and the one implemented directly in the university classroom are being erased. The term "e-learning" reflects the integration of distance and traditional organization of the educational process on the basis of ICT.

The aim of this paper is to present a review of literature on e-learning, to explore its advantages and disadvantages, and to analyze the survey results of the implementation of e-learning among 67 students trained at the Institute of Non-Destructive Testing of National Research Tomsk Polytechnic University. The study employed the following methods: literature review, survey and data analysis.

\section{Background literature}

E-learning is gradually growing and has become a part of university education. Universities develop a variety of courses to satisfy student learning needs and improve employee effectiveness [1]. Literature on e-learning

\footnotetext{
${ }^{\mathrm{a}}$ Corresponding author: mkuimova@mail.ru
}

implementation proves that it helps not only to deliver the content and materials of the course, but also to improve student academic achievement [2]. E-learning engages students in the learning process, provides opportunities for students' online activities at their own pace and at the time convenient for them. It creates learning situations and makes learners responsible for their own learning. Additionally, e-learning improves learners' time-management skills, ability to coordinate their study time and an opportunity to skip the elements they do not need [3-5].

Modern educational technologies and e-learning technologies are student-centered and are focused on the development of individual student resources [6-10]. Elearning has a number of advantages; it:

- provides an opportunity for university teachers to study colleagues' experiences, thus providing a chance of continual retraining;

- provides better teaching aids, their efficient, timely updating and availability;

- facilitates flexible asynchronous learning;

- provides learners with a sense of autonomy and control;

- provides a personal work schedule and a list of students' training courses tailored to their interests within the framework of educational standards;

- intensifies the students' learning and cognitive activities;

- forms critical thinking skills, initiative and responsibility for the work;

- develops student's ability to work independently; 
- contributes to the students' professional competencies;

- ensures lifelong learning by removing spatial and temporal restrictions [11-13].

Despite many advantages, e-learning has some disadvantages. They are:

- lack of full-time direct communication between students and teachers (when there is no person who could emotionalize the knowledge);

- difficulty in establishing a creative atmosphere among the students of one group;

- difficulty in motivating students;

- computer anxiety, time spent on learning and mastering the technical aspects of doing the online course;

- the use of the e-learning system by lecturers might increase student perception that it makes student life easier $[1,14,15]$.

After reviewing the literature, it can be concluded that e-learning meets the increased demands for enhanced teaching methods, makes enormous advances in the quality of teaching, offers flexible opportunities for learning and supports continuous inquiry. The launch and development of e-learning in educational institutions require much effort; they must have:

- necessary qualified experts and teachers to introduce educational programs;

- equipment to introduce new educational programs and ensure their implementation;

- qualified technical personnel to provide smooth functioning of the equipment.

\section{Discussion and research}

Currently, there is a tendency to strengthen professional competences of university graduates. The core mission of higher education is to enable people to learn. Higher education needs to become more outward looking and innovative, because society needs creative, enterprising, independent and responsible engineers who are equipped for the challenges of today's changing world. The Russian educational policy reflects the national interests in the field of education and takes into account the overall global trends:

- democratization of society (enhancement of a political and social choice, which creates the need to raise the level of citizens' readiness for this choice);

- transition to a post-industrial, information society;

- dynamic development of economy;

- competitive expansion;

- deep structural changes in employment (reduction of the scope of unskilled and low-skilled labor);

- the constant need to improve training and retraining of workers;

- the increase of professional mobility;

- the need to prepare people for life in a rapidly changing environment;
- significant expansion of cross-cultural interaction, where communication and tolerance become particularly important factors;

The Russian state guarantees the availability of high quality education, by means of:

- training with the use of modern equipment and teaching materials;

- training in conditions that guarantee the protection of the individual's rights, identity in the educational process, and her or his psychological and physical security;

- socio-pedagogical and psycho-pedagogical assistance to the family and early assessment of the child's developmental reserves (physical and psychological);

- free use of the public library funds, visitation of state museums and municipal cultural institutions.

To meet the needs of a knowledge-driven and knowledge-dependent society as well as to provide a broadly-competent labor market and universities, which equip students with competencies to make the best use of their talents and opportunities. In addition, universities should ensure the availability of the well-trained academic staff as well as:

- arrangement of opportunities for the continuous professional development of the staff;

- facilitation of communication among teachers;

- development of inter-subject connections and communication;

- introduction of various teaching methods and educational settings;

- provision of up-to-date and high-quality materials for lessons.

Furthermore, universities should foster the awareness of new challenges and provide curricula that imply:

- preference of research over teaching;

- active student involvement in curricular design and review procedures;

- development of students' diverse interests and needs.

Achieving the high level of university graduates training is no easy task. Inspiring teachers and high quality teaching is the lynchpin of the higher education learning environment. Teaching and learning is a shared process, imparting responsibilities to both a student and a teacher. Teaching blooms in a research-rich environment. Such an environment teaches conducting better-targeted research, provides authentic, real-world tasks and gives students opportunities to apply skills or knowledge in diverse contexts. Moreover, it:

- teaches to apply classroom-gathered knowledge to real-world problems;

- motivates students;

- inspires and enables the development of students capabilities;

- applies classroom-gathered knowledge to realworld problems;

- increases students knowledge and understanding;

- teaches to collect, synthesize, and analyze information; 
- generates hypotheses and coherent explanations;

- develops flexible problem solving and reasoning skills;

- contributes to the overall creation, sharing and evaluation of knowledge.

Higher education aims to prepare a competitive, qualified graduate who is fluent in her or his profession, able to navigate in the related fields of activity, capable of efficient operation in the specialty at the level of world standards, and ready for continuous professional development, social and professional mobility. To provide a high-end higher education, the Russian Federation:

- introduces new state educational standards of education;

- implements a flexible profile training in high schools;

- supports small and rural schools;

- broadens the variety of educational programs;

- provides continuity of education;

- strengthens the role of disciplines to ensure successful socialization of students and their integration into the employment relationship;

- introduces new educational technologies and actively uses "open education" technologies;

- extends distance learning;

- increases the role of students' independent work.

Additionally, universities introduce a range of innovative teaching methods and techniques: e-learning, experiential learning, problem-based learning, projectbased learning, case-based learning, etc. The higher educational environment trains students to be courageous in openness to new ideas, promotes curiosity to seek new solutions and encourages students to develop:

- strong community engagement;

- a sense of ethical responsibility;

- confidence in their abilities;

- lifelong curiosity and commitment;

- adaptable, assured, innovative and entrepreneurial skills.

National Research Tomsk Polytechnic University (TPU) also encourages and incentivizes best teaching practices and e-learning in its curricula, which helps to train in-demand specialists and improve the university position in the QS World University Rankings [16]. We have analyzed the position of the university in 2013 (Table 1) and in 2015 (Table 2).

The positive dynamics of TPU's position in the QS World University Rankings proves the effectiveness of its teaching practices.

Table 1. QS World University Rankings of 2013, Russian Universities, Top 600.

\begin{tabular}{|l|l|}
\hline \multicolumn{1}{|c|}{ Rank } & \multicolumn{1}{c|}{ University } \\
\hline $\mathbf{1 2 0}$ & Lomonosov Moscow State University \\
\hline $\mathbf{2 4 0}$ & Saint-Petersburg State University \\
\hline $\mathbf{3 3 4}$ & Bauman Moscow State Technical University \\
\hline $\mathbf{3 5 2}$ & Novosibirsk State University \\
\hline $\mathbf{3 8 6}$ & $\begin{array}{l}\text { Moscow State Institute of International } \\
\text { Relations (MGIMO University) }\end{array}$ \\
\hline
\end{tabular}

\begin{tabular}{|l|l|}
\hline $\mathbf{4 4 1 - 4 5 0}$ & $\begin{array}{l}\text { Moscow Institute of Physics and Technology } \\
\text { (MIPT / Moscow Phystech) }\end{array}$ \\
\hline $\mathbf{4 5 1 - 4 6 0}$ & $\begin{array}{l}\text { Peter the Great Saint-Petersburg Polytechnic } \\
\text { University }\end{array}$ \\
\hline $\mathbf{4 9 1 - 5 0 0}$ & Peoples' Friendship University of Russia \\
\hline $\mathbf{5 0 1 - 5 5 0}$ & $\begin{array}{l}\text { National Research University Higher School } \\
\text { of Economics (HSE, Moscow) }\end{array}$ \\
\hline $\mathbf{5 0 1 - 5 5 0}$ & Ural Federal University \\
\hline $\mathbf{5 5 1 - 6 0 0}$ & $\begin{array}{l}\text { National Research Tomsk Polytechnic } \\
\text { University }\end{array}$ \\
\hline $\mathbf{5 5 1 - 6 0 0}$ & Tomsk State University \\
\hline
\end{tabular}

Table 2. QS World University Rankings of 2015/16, Russian Universities, Top 600.

\begin{tabular}{|c|c|}
\hline Rank & University \\
\hline 108 & Lomonosov Moscow State University \\
\hline 256 & Saint-Petersburg State University \\
\hline 317 & Novosibirsk State University \\
\hline 338 & $\begin{array}{l}\text { Bauman Moscow State Technical } \\
\text { University }\end{array}$ \\
\hline 397 & $\begin{array}{l}\text { Moscow State Institute of International } \\
\text { Relations (MGIMO University) }\end{array}$ \\
\hline $431-440$ & $\begin{array}{l}\text { Moscow Institute of Physics and } \\
\text { Technology (MIPT / Moscow Phystech) }\end{array}$ \\
\hline $471-480$ & $\begin{array}{l}\text { Peter the Great Saint-Petersburg } \\
\text { Polytechnic University }\end{array}$ \\
\hline 481-490 & $\begin{array}{l}\text { National Research Tomsk Polytechnic } \\
\text { University }\end{array}$ \\
\hline $481-490$ & Tomsk State University \\
\hline $501-550$ & $\begin{array}{l}\text { National Research Nuclear University } \\
\text { MEPhI (Moscow Engineering Physics } \\
\text { Institute) }\end{array}$ \\
\hline $501-550$ & $\begin{array}{l}\text { National Research University Higher } \\
\text { School of Economics (HSE, Moscow) }\end{array}$ \\
\hline $551-600$ & Kazan (Volga region) Federal University \\
\hline
\end{tabular}

It is generally admitted that the use of technology increases the efficiency of higher education, reveals new horizons for self-study, raises self-esteem of all participants of the educational process and the image of the teacher in the eyes of students. Modern students are a network generation. As practice shows, an electronic way of getting information is a commonplace for them. They easily adapt to an electronic information educational environment of a modern university.

E-learning is becoming increasingly popular in fulltime education. It implies a variety of formats, including learning through interactive lectures by the best teachers, interactive tests (including audio-visual), distant execution of virtual laboratory and practical work which provide the opportunity of teacher's control and modeling of the processes simulating reality, organization of network project activities, creation of network communities, etc. In addition, e-learning ensures systematic support of individual training, network consultations both online and offline, efficiency of communications, individualization of learning, a flexible and convenient training schedule and an increase of motivation to learn. E-learning favors the opportunity to:

- get current knowledge at any time and anywhere 
in the world;

- form informational culture;

- implement project activities;

- expand communicative components of educational activities and distant interaction;

- organize independent work;

- open up new possibilities for creative work.

TPU actively introduces e-learning to provide quality education and to respond to the needs of the university, staff and students. Undoubtedly, evaluation of e-learning is a hard and tough research; we are just going to investigate students' general opinion of e-learning courses for language learners. We researched students' opinions of the courses based on the e-learning platform, Moodle, developed for foreign language practice; we polled 67 second-year students trained at the Institute of Non-Destructive Testing of National Research Tomsk Polytechnic University to evaluate their experience. The students worked with different e-learning courses (developed by TPU language teachers) during two semesters.

The respondents were asked to give their opinion of e-learning courses and to estimate their practicality by answering a number of questions. They might choose: Very good, Good, Poor, Don't know.

Table 3. The questions asked and students' answers.

\begin{tabular}{|l|c|c|c|c|}
\hline \multicolumn{1}{|c|}{ Questions } & \multicolumn{4}{|c|}{ Answers } \\
\cline { 2 - 5 } & $\begin{array}{c}\text { Very } \\
\text { good } \\
\text { (\%) }\end{array}$ & $\begin{array}{c}\text { Good } \\
\text { (\%) }\end{array}$ & $\begin{array}{c}\text { Poor } \\
\text { (\%) }\end{array}$ & $\begin{array}{c}\text { Don't } \\
\text { know } \\
\text { (\%) }\end{array}$ \\
\hline \multicolumn{3}{|c|}{ Layout } \\
\hline $\begin{array}{l}\text { interface of the } \\
\text { courses }\end{array}$ & 78 & 12 & 4 & 6 \\
\hline $\begin{array}{l}\text { consistent } \\
\text { organization of the } \\
\text { components } \\
\text { through the course }\end{array}$ & 96 & 4 & - & - \\
\hline $\begin{array}{l}\text { tables and graphs } \\
\text { clarifying the text } \\
\text { information }\end{array}$ & 87 & 9 & - & 4 \\
\hline $\begin{array}{l}\text { instructions, } \\
\text { directions, } \\
\text { navigation and } \\
\text { definitions }\end{array}$ & 91 & 6 & - & 3 \\
\hline $\begin{array}{l}\text { convenience of the } \\
\text { work with e- } \\
\text { learning courses }\end{array}$ & 85 & 7 & 3 & 5 \\
\hline $\begin{array}{l}|c| \\
\text { correlation with } \\
\text { the curriculum }\end{array}$ & 97 & 3 & - & - \\
\hline $\begin{array}{l}\text { the content fosters } \\
\text { active } \\
\text { opportunities }\end{array}$ & 84 & 7 & 3 & 6 \\
\hline
\end{tabular}

\begin{tabular}{|l|c|c|c|c|}
\hline \multicolumn{5}{|c|}{ Course content } \\
\hline $\begin{array}{l}\text { a combination of } \\
\text { theoretical and } \\
\text { practical material }\end{array}$ & 81 & 13 & 3 & 3 \\
\hline $\begin{array}{l}\text { topicality of the } \\
\text { material }\end{array}$ & 79 & 18 & 3 & - \\
\hline $\begin{array}{l}\text { practical of } \\
\text { significance }\end{array}$ & 88 & 9 & - & 3 \\
\hline $\begin{array}{l}\text { amount } \\
\text { interaction/commu } \\
\text { nication with other } \\
\text { students }\end{array}$ & 29 & 7 & 3 \\
\hline $\begin{array}{l}\text { amount } \\
\text { interaction/commu } \\
\text { nication with a } \\
\text { teacher }\end{array}$ & 69 & 31 & - & - \\
\hline $\begin{array}{l}\text { course assistance } \\
\text { in preparation for } \\
\text { the pass/fail exam } \\
\text { or examination }\end{array}$ & 70 & 25 & 2 & 3 \\
\hline $\begin{array}{l}|c| \\
\text { apprehensibility of } \\
\text { the evaluation } \\
\text { criteria }\end{array}$ & 96 & 4 & - & - \\
\hline $\begin{array}{l}\text { participation in on- } \\
\text { line testing } \\
\text { outcomes }\end{array}$ & 92 & 8 & - & - \\
\hline $\begin{array}{l}\text { documentation of } \\
\text { aching and }\end{array}$ & 94 & 6 & - & - \\
\hline
\end{tabular}

Thus, the research proved the efficiency and effectiveness of e-learning courses and highlighted their following benefits: convenience, consistent organization of the components through the course, correlation with the curriculum, combination of theoretical and practical material, apprehensibility of the assessment criteria and their documentation. E-learning courses allow being engaged in the most comfortable mode and managing time efficiently, providing useful theoretical and practical material. Furthermore, on-line tests are one of the most useful tools in e-learning; the system automatically evaluates students' knowledge and provides a teacher with an opportunity to see the most difficult issues of the course for learning and respectively paying special attention to them in practical lessons and seminars. Shortages of interaction with peers and a teacher need to be improved a bit. Beyond dispute, technology can not completely replace live communication of a student with the teacher (at least not yet). Nevertheless, developing courses in e-learning on the Moodle platform, teachers should use tools to motivate communication and foresee more tasks for it. 
Thus, e-learning is a powerful tool that improves knowledge sharing and quality of education through the use of fast replenished world educational resources, the expansion of the range of university's educational services, the increase of the attractiveness of the studied material by upturning the conditions of education. It provides comfortable conditions (workplace, freedom of time and choice for training), enhances the level of students' independent work at their own pace, enables operative assessment of the acquired knowledge, and boosts the level of self-motivation, responsibility and self-discipline.

\section{References}

1. B. Naresh, D.B.S. Reddy, MJSS, 6(5), 484-489 (2015)

2. A.K.M.N. Islam, TELEMAT INFORM, 33(1), 4855 (2015)

3. N. Songkram, J. Khlaisang, B. Puthaseranee, M. Likhitdamrongkiat, Procedia Soc. Behav. Sci, 174, 667-673 (2015)

4. G.C. Oproiu, Procedia Soc. Behav. Sci, 180, 426432 (2015)

5. L.E. Nugroho, iJET, 11(01), 62-65 (2016)

6. A. Matei, C. Vrabie, Procedia Soc Behav Sci, 93, 526-530 (2013)

7. M.V. Kuimova, D.A. Polyushko, iJET, 10(1), 72-73 (2015)

8. A.V. Ruchina, M.V. Kuimova, D.A. Polyushko, A.E. Sentsov, Zhang Xue Jin, Procedia Soc. Behav. Sci, 215, 98-101 (2015)

9. M.V. Kuimova, O.D. Zvekov, iJET, 11(4), 157-160 (2016)

10. M. Kimova, D. Burleigh, A. Trofimova, MATEC Web Conf., 48, 5 (2016)

11. A. Labus, M. Despotović-Zrakić, B. Radenković, Z. Bogdanović, M. Radenković, JCAL, 31(6), 592-605 (2015)

12. R.I. Bazhenov, D.V. Luchaninov, Life Sci J., 11(11), 371-374 (2014)

13. H.B. Santoso, M. Schrepp, R. Yugo Kartono Isal, A.Y. Utomo, B. Priyogi, JEO, 13(1), 58-79 (2016)

14. M. Klement, J. Dostál, Procedia Soc. Behav. Sci, 128, 175-180 (2014)

15. L.W.H. Michael, N.Z.M. Saat, K. Sazlina, H. Siti Aishah, M.R. Suzielawati, S.N. Nurul, T. Ketharin, M. Anisah, A.M.A. Nor, RJASET, 9(11), 990-994 (2015)

16. QS

Top Univ.,

URL:

http://www.topuniversities.com/university-rankings (access date 15.02.2016) 